\title{
Opportunities and constraints to improving milk quality in Ireland: Enabling change through collective action
}

\author{
C. Devitt, ${ }^{\star 1}$ K. McKenzie, † S. J. More,‡ K. Heanue,§ and F. McCoy\# \\ *Glendalough, Co. Wicklow, Ireland \\ †School of Psychology, Trinity College, Dublin, Ireland \\ ¥Centre for Veterinary Epidemiology and Risk Analysis, UCD Veterinary Medicine, University College Dublin, Dublin 4, Ireland \\ §Rural Economy and Development Program, Teagasc Mellows Campus, Athenry, Co. Galway, Ireland \\ \#Animal Health Ireland, Carrick-on-Shannon, Co. Leitrim, Ireland
}

\section{ABSTRACT}

Ireland plays a key role in contributing to the global supply of dairy produce, and increasing international demand, as well as the abolition of milk quotas in the European Union in 2015, present opportunities for the Irish milk industry. Improving milk quality is required to maximize these opportunities. National action on milk quality is spearheaded by Animal Health Ireland, yet the potential for collective action at an industry level is undermined by the inability of individual stakeholders to accept responsibility for action. In-depth qualitative interviews were conducted with $\mathrm{n}=12$ stakeholder representatives. The theoretical concepts of collective action (i.e., when a group of people with a shared interest undertake some kind of voluntary common action in pursuit of that shared interest) is applied to understanding the results and identifying a collective way forward. Though consensus is apparent on the need to improve milk quality, differences exist about individual responsibility and the best way to achieve higher quality standards. The propensity for collective action is undermined by shifting responsibility to other stakeholders, stakeholder positions, trust concerns, and concerns over the commitment of other stakeholders to cooperate. Understanding how collective action works provides Animal Health Ireland with a knowledge framework in which to build stakeholder consensus. The paper concludes with practical examples of how Animal Health Ireland continues to apply this understanding by bringing individual stakeholders together to achieve milk quality improvement.

Key words: collective action, cooperation, milk quality, Animal Health Ireland

Received July 31, 2012.

Accepted December 19, 2012.

${ }^{1}$ Corresponding author: catherine.devitt@ucd.ie

\section{INTRODUCTION}

\section{The Irish Dairy Industry}

The Irish dairy industry is an important contributor to the world trade in dairy products. Although global output is relatively small (approximately 5.2 million tonnes of milk in 2009; International Dairy Federation, 2009 ), over $80 \%$ of dairy production in Ireland is exported to the value of approximately $€ 2.4$ billion in 2011 (Department of Agriculture, Food and the Marine, 2012). In 2007, the key outputs from the processing industry included butterfat $(147,000 \mathrm{t})$, cheese $(136,000$ t), skim milk powder or buttermilk powder $(88,000$ t), chocolate crumb (a dry blend of milk, cocoa, and sugar; 45,000 t), whole milk powder $(38,000 \mathrm{t}$ ), and CN $(40,000$ t). Since 2005 , a marked increase in the production of cheese and skim milk powders, and a decrease in choc crumb and $\mathrm{CN}$ has been observed (Irish Business and Employers Confederation, 2007). Critically, Ireland produces $15 \%$ of the global supply of infant formula (Irish Business and Employers Confederation, 2011). Dairy production is predominantly based on a springcalving, pasture-based system (Creighton et al., 2011). In 2010, Ireland had approximately 1.1 million dairy cows and 27,414 dairy farms, with an average of 39.9 dairy cows per farm (Central Statistics Office, 2010). The national processing industry is fragmented, with 6 main processors drawing from regionally distinct areas. It is anticipated that milk production will expand significantly - by up to $50 \%$ by 2020 - given the increasing international demand for milk and milk products and the expected abolition of milk quotas in the European Union in 2015 (Department of Agriculture, Food and the Marine, 2010).

\section{The Need for Collective Change}

The Irish industry faces some key challenges as it seeks to maximize its potential. Udder health is a concern on several Irish dairy farms, and improve- 
ments in milk quality have been identified as one way to maximize competitiveness and the marketability of Irish dairy products in a growing international market (More, 2007, 2009; More et al., 2010, 2012). Food Harvest 2020, which outlines an ambitious strategy for expansion of the Irish agri-food sector, refers to the need for all relevant agencies to encourage the adoption of best practices in animal health to improve productivity and competitiveness in international markets.

National action toward improved milk quality is being coordinated in Ireland by Animal Health Ireland (AHI), an organization established in 2009 to provide a partnership approach to the control of nonregulatory diseases by bringing together stakeholders concerned with animal health issues (More et al., 2011). A key outcome from a recent study utilizing policy Delphi methodology (More et al., 2010), was that stakeholders need to recognize, to a greater extent, their own responsibility to work together to control diseases such as mastitis, which have elements of both public good and private good (for ease of access, key terms used within this paper are italicized at first use and explained in Table 1). The study also found that challenges exist in generating consensus, shared responsibility, and collective action, particularly around animal health issues such as mastitis (More et al., 2010). Improvements to udder health and milk quality are of broader benefit (to Ireland as a whole and to the overall Irish dairy industry), as well as being of benefit to individuals (processors and farmers) within the industry. Collective action is a logical approach to udder health concerns in Ireland, given the lack of sustained success in past attempts, the fragmented nature of the industry (but the potential gain to all if these concerns were successfully addressed), and the potential benefits from a collective response, including the pooling of national expertise and scarce resources.

\section{The Theoretical Concept of Collective Action}

The use of the concept of collective action is common across the human sciences, where the seminal work by Ostrom and her research team is heavily cited (Ostrom, 2000). Collective action is the involvement of a group of people with a shared interest undertaking some kind of voluntary common action in pursuit of that shared interest (Meinzen-Dick et al., 2004). The literature points to several challenges to achieving collective action, 4 of which are pertinent for the purposes of this paper:

1. The propensity for collective action can be attributed to how stakeholders see their own and others responsibility and the perceived efficacy of one's contribution to the collective good (Kreps et al., 1982; Ostrom, 2000). Fleishman (1980) argued that, though a high level of perceived responsibility can contribute to action, the recognized phenomenon of surplus resources - the more stakeholders that are involved can lead to a belief that one's contribution is not required or as significant-is also relevant. This can result in bystanders, that is, stakeholders who choose not to contribute (Schwartz and Gottlieb, 1976; Fleishman, 1980; Anker and Feeley, 2011).

2. The tendency for free-riding has been noted to take root; this is when individual benefits are gained from a public good without any contribution being made to the costs of providing that good (Hardin, 1968; Stigler, 1974; Libecap, 1989). This problem is pervasive across many situations and is illustrated by the shifting of responsibility and associated costs to other actors. This problem presents "a barrier to the evolution and persistence of collective action" (Delton et al., 2012), as the likelihood of collective action taking place and the overall expected gain for all stakeholders involved is reduced (Stigler, 1974).

3. The propensity for collective action is also threatened by the emergence of veto players. Veto players are those who know that a joint venture cannot continue if they withdraw their assent and cooperation. The agreement of other actors to the said joint venture work is made with the knowledge that they may only proceed if the veto player(s) is satisfied and does not withdraw their contributed action (Tsebelis, 1995, 2002).

4. Finally, conditional cooperators base their actions on the belief of whether and how much others should contribute (Ostrom, 2000; Potette et al., 2010), whereby an element of mind reading and attribution occurs, such that an actor(s) has a firm belief as to what another actor(s) can and should contribute.

\section{Ways to Achieve Collective Action}

Collective action can be achieved by excluding those that do not contribute collectively, by creating incentives to encourage contribution, and by reducing the expected gain for individuals so that it is lower for those who do not contribute (Ostrom et al., 1992; Raihani and Aitken, 2011; Delton et al., 2012). Facilitated communication processes and building a collective identity are important to encourage agreement among different stakeholders (Ostrom et al., 1992; Sally, 1995; Klandermans et al., 2002). This is particularly necessary when a competitive relationship exists between stakeholders who are also orienting toward a common goal (Bengts- 
Table 1. Key terms used in the paper (terms presented in italics in manuscript)

\begin{tabular}{|c|c|c|}
\hline Key term & Theoretical meaning & Examples \\
\hline Collective action & $\begin{array}{l}\text { When a group of individuals, brought together by a common } \\
\text { interest (e.g., milk quality), seek to serve that interest } \\
\text { collectively (Meinzen-Dick et al., 2004; see also Cook, 1997, for } \\
\text { an outline of collective action among user oriented firms in the } \\
\text { history of the American dairy industry). Self-interests within } \\
\text { a group, however, may translate into individuals deciding not } \\
\text { to act toward achieving a common goal (Olson, 1971; Sandler, } \\
\text { 1992). }\end{array}$ & $\begin{array}{l}\text { For example, collective action as a response } \\
\text { to global climate change. It is in every } \\
\text { country's interest to act collectively, despite } \\
\text { the costs and benefits differing for each } \\
\text { country (Adger, 2003; Stern, 2007; Sandler, } \\
\text { 2004). Failure to act collectively arises from } \\
\text { individual national interests. }\end{array}$ \\
\hline Conditional cooperators & $\begin{array}{l}\text { An individual who contributes to the public good only if other } \\
\text { individuals within the group also contribute (Ostrom, 2000; } \\
\text { Szolnoki and Perc, 2012). }\end{array}$ & $\begin{array}{l}\text { Tingley and Tomz }(2012) \text { explore the role of } \\
\text { conditional cooperation in relation to global } \\
\text { climate change strategies. }\end{array}$ \\
\hline Free rider & $\begin{array}{l}\text { An individual who benefits from something without paying for } \\
\text { it. This occurs when that individual consumes more than their } \\
\text { equal share of a common resource, or pays less than their fair } \\
\text { share toward the cost of that common resource (Ostrom, 2000; } \\
\text { Delton et al., 2012). }\end{array}$ & $\begin{array}{l}\text { An individual who uses public transport } \\
\text { without paying the required fee. }\end{array}$ \\
\hline Public good & $\begin{array}{l}\text { A product that is available to all. The product can be } \\
\text { consumed without it being reduced for others and cannot } \\
\text { be removed from one individual without it being removed } \\
\text { from all (Stroebe and Frey, 1982; Holcombe, 1997; Kaul and } \\
\text { Gleicher, 2011). A public good is also known as a collective } \\
\text { good. }\end{array}$ & $\begin{array}{l}\text { Examples include environmental goods such } \\
\text { as air, water, a public or national park, } \\
\text { among others. }\end{array}$ \\
\hline Regulatory capture & $\begin{array}{l}\text { The regulator is persuaded to operate in the industry's } \\
\text { interests rather than those of the consumer. }\end{array}$ & $\begin{array}{l}\text { A commonly cited historical example is that } \\
\text { of the Interstate Commerce Commission, } \\
\text { which was accused of serving specific } \\
\text { interests over the wider regulation of } \\
\text { railroads in the US, which was its primary } \\
\text { purpose (Stone, 1991). }\end{array}$ \\
\hline Veto player & $\begin{array}{l}\text { An individual who has to agree with the group collective in } \\
\text { order for change to occur, but can stop or veto the change } \\
\text { from taking place (Tsebelis, 2002). }\end{array}$ & $\begin{array}{l}\text { For example, the US Constitution requires } \\
\text { that legislation be approved by the } \\
\text { President, the House, and the Senate. These } \\
\text { are all potential veto players (Tsebelis, } \\
\text { 2002) to legislative change taking place. }\end{array}$ \\
\hline
\end{tabular}

son and Kock, 2000). Collective action can involve an altruistic individual, or initiator, willing to expose his or herself to personal loss to encourage and facilitate collective action within the wider group (Ostrom, 2000; Ahn et al., 2001; Raymond, 2006). This may also be an initiator who is in a position to recognize threats and opportunities to collective action and devise strategies to deal with such accordingly (Bianchi, 2001; Lamprinopoulou et al. 2006). A critical role is played by trust (Raymond, 2006), and trust-building can come from increased positive interaction and the development of a history of cooperation within the group (Ostrom, 1990, 2000; Ahn et al., 2001; Raymond, 2006).

\section{Examples of Collective Action in the Agricultural Sciences}

Within the agricultural sciences, examples of the application of collective action in the organization of milk cooperatives exist (Nilsson and van Dijk, 1997; Armentano et al., 2004; Le Cren et al., 2009), for example, extension programs involving advisors and dairy farmers and building industry capacity (Brightling et al., 2005; Doyle et al., 2010; Nettle et al., 2010) and understanding bio-security behavior among farmers in the United Kingdom (Heffernan et al., 2008). Heffernan et al. (2008) show that responsibility for action on biosecurity measures in the United Kingdom and across Europe (Heffernan et al., 2005) is shifted elsewhere (e.g., to the "bad farmer"; Heffernan et al., 2008), or is undermined by the concerns over the commitment of others to act responsibly (Heffernan et al., 2005). Low levels of trust among farmers explained a poor collective approach to implementing bio-security measures (Heffernan et al., 2008). As noted in Lamprinopoulou et al. (2006) on collective action in the Greek agri-food sector, higher levels of trust and reciprocity reduce transaction and coordination costs. Trust is central, 
because actors are likely to think that other actors are motivated solely by what benefits will accrue to them, rather than the total merged collective entity.

\section{Study Objectives}

In this paper, the concept of collective action and the barriers to achieving it are applied to understanding the constraints and opportunities to achieving collective action on milk quality improvement in Ireland. The paper applies the 4 theoretical understandings of collective action (as outlined above) to an understanding of results from interviews with industry stakeholders. The paper concludes with examples of how AHI is bringing together stakeholders to develop collective action.

\section{MATERIALS AND METHODS}

In 2011, a research steering group was established to guide the social science component of CellCheck, a national mastitis control program coordinated by AHI. To explore the industry landscape in which the program was being developed, the steering group conducted a small qualitative research study to gather insight and perspective on the industry's strengths and weakness from members of the industry itself. This exercise provided an understanding of the industry environment, and the challenges, barriers and opportunities for milk quality improvement. Members of the CellCheck Industry Consultation Group (ICG) were informed of the process before commencement and representatives from stakeholder organizations were informed that they would be invited to participate in the study. Twelve participants were selected from stakeholder groups in AHI (the Department of Agriculture, Food and the Marine, DAFM; advisory organizations; other service provider organizations; milk processors; and farm organizations); all play pivotal roles in the Irish dairy industry, and all agreed to participate.

In-depth qualitative interviews were conducted, and areas explored during the interviews included: the role of organizations in milk quality improvement; the political, economic, social, and technological challenges and barriers to improving milk quality; and the opportunities and incentives for progression. Verbal consent from participants was sought before interview commencement and interviews lasted $40 \mathrm{~min}$, on average. All interviews were recorded and transcribed and transcripts were anonymized, removing any identifiable information. NVivo (QSR International Pty Ltd., Melbourne, Australia) was used to assist the data analysis process and data was analyzed using thematic analysis. This involved the development of codes and categories that reflected meaning from the data and was based on the guidelines given by Attride-Stirling (2001). Three steps were taken: (1) development of basic codes that described the content of the interview; (2) greater familiarization with the data and subsequent development of second-level categories showing a human science explanation of issues arising from the data; and (3) grouping together these categories into broad analytical themes. A summary of the results was presented to the CellCheck ICG for feedback and comment.

\section{RESULTS}

\section{Constraints to Achieving Collective Action Toward Improved Milk Quality in Ireland}

Shifting Responsibility Elsewhere: Stakeholder Passivity. Widespread agreement was found across the participant group on the need to define quality away from the regulatory standard for SCC of 400,000 cells/mL in milk, as defined in European Council Directive $92 / 46 / \mathrm{EEC}$, and implemented by DAFM. This level of SCC acceptance was described as a "rejection standard," meaning that "there is no difference between high quality milk and legally acceptable milk." Despite this agreement, a shifting of responsibility to other stakeholders within the industry to act on milk quality improvement was evident from participant responses when determining their own willingness to contribute to milk quality initiatives. Commitment to individual organizational remits was cited as the main reason for not acting directly on milk quality improvement, though results suggest that it is presumed by individual stakeholders that other, perhaps better positioned, stakeholders within AHI accrue more benefits, and therefore should bear greater costs and responsibilities. For example, one participant reported that, "We don't have a mission to improve milk quality ... our mission is a higher altitude than that, it's about securing the best possible incomes and livelihoods for dairy farmers...I would not tell a farmer how to run his business... it's up to $<$ a specified organization $>$ and the cooperatives [milk processors] that collect the milk."

Stakeholders, other than milk processors, prioritized the responsibility of processors in facilitating and promoting change in milk quality standards at the farm level through the existing system of payment for milk. This is apparent in the following stakeholder statements: "The problem could be solved if the stick was used properly... if co-ops took the same attitude to milk quality, not geometric averaging..."; "It's really up to the manufacturers to improve the quality..."; and "Coops need to pick up the issue, and they have to drive it because milk is a commodity." At the same time, processors perceived this responsibility unfavorably: 
"Everything is left on the processor...[for example] DAFM just want to implement regulation, [but are] not interested in the quality or the customers or clients."

The expected role and responsibility of DAFM was clear. Half of the participant group explicitly identified concerns over the lack of governance and passivity of DAFM in failing to implement and police regulatory standards: "The departments are meant to police, this is not happening." The concept of regulatory capture is reported as being, "so complete the government doesn't see it anymore." Though DAFM acknowledged the difference between regulation standards and the actual level that should define milk quality, they defined their responsibility in enforcing regulation, not in bridging any gap between regulatory standards and a desired standard of quality: "All areas of the department can't be involved in improving milk quality, that role is invested in $<$ a specified organization $>\ldots$ we allow the industry to self-regulate in relation to improving milk quality above the regulatory standards, these standards are easy to achieve."

Other participants placed responsibility at the farm advisory level because of their available resources, their role in the provision of information, and their proximity to the farm level. The adoption of a bystander role by many stakeholders is evident, as they take an inactive, passive stand and shift responsibility to other stakeholders, rather than recognizing the potential for their own input. Statements also reflect the possibility of free-riding, whereby benefits are gained from a public good without any contribution being made to the costs of providing and maintaining that good.

The Emergence of Veto Players: Stakeholder Positions in Identifying How to Improve Milk Quality. Agreeing on acceptable SCC levels and a bonus- or penalty-led approach for milk quality were cited as the 2 main areas for action on milk quality improvement. Despite widespread consensus on the need to improve milk quality, conflicting views were noted among the participant group on how best to promote, encourage, and facilitate a concerted effort to improve milk quality among industry members and dairy farmers. Though a bonus-led approach (i.e., rewarding milk producers for quality milk) was regarded by the majority of stakeholders as providing a more effective way of raising quality standards, a penalty-led approach was favored by others. Evidence suggests the emergence of veto players among the stakeholders, whereby the willingness to contribute and cooperate is withdrawn because of reported political and economic positions. In some cases, cited reasons for disagreement included adherence to individual organizational positions; for example, this participant expressed a favorable percep- tion of a bonus-led approach but clearly stated that, "politically, we cannot argue in favor of penalties." Political positions are seen to affect the willingness of some stakeholders to take the lead on improving quality: " $<$ Stakeholder group $>$ are so powerful - the government won't do anything to aggravate the situation." Economic reasons were cited by milk processors, with concerns on how a bonus approach could be feasibly implementable and economically viable for the milk processing level specifically cited:"Farmers argue that penalties should be reduced if you give a bonus-yet you have to make money on the bonus to make it realizable - [therefore, it is] not economically viable $<$ for processors $>$ for a bonus. Perception is that if co-ops give a bonus, everyone would say that cell count would improve. To give a bonus, you need money to give it..."

Milk processors expressed concerns about facilitating a bonus-led system, for fear of appearing to place "coop farmers [farmers supplying milk to a specific milk processor] at an advantage above non-co-op farmers [farmers supplying milk to a different milk processor]... we must follow what other co-ops [milk processors] are doing... often penalties and bonuses are seen as a way of adjusting milk price." It is not possible to decipher from the results whether or not these positions are prioritized over the good of the industry or, rather, that they are not fully aligned with the industry. Though the intention to act as veto players is not explicitly acknowledged, support for this suggestion from other participant responses exists. Five participants referred to relations within the industry as being, for example: "a complex web, with self-interests"; " $<$ there being $>$ vested interests dictating a lot of what happens"; and "individual positions impacting on the decisions around the table." For one of these participants, progress on improvement is "repeatedly stalled as certain standpoints get in the way of there being real action." These perceptions may reflect a lack of trust between stakeholders. Nevertheless, differences in stakeholder consensus reduces the propensity for reaching consensus on defining the ways in which on-farm improvement can be implemented (i.e., whether through a bonus- or penalty-led approach).

Conditional Cooperation: The Effect of Trust Concerns. Despite agreement on the need to address milk quality concerns, predominant viewpoints reflected a lack of trust pertaining to the sharing of information about to individual stakeholder positions. Referring to a reduced willingness to openness and sharing at meetings as a result of these trust concerns, one participant explained: "I feel we have to be careful at meetings, we have to be careful with what we say." Another reported: "It's hard to lay everything on the table when you just 
don't know how it will be interpreted or used by others around the table..." A lack of trust between stakeholders is seen as getting in the way of progress on joint action and national progress: "We need to measure progress. We don't have a national statistic on SCC - [it] hasn't been collected, some people feel that a national statistic would be high and then used against us." A belief has been noted that quality performance needs to be quantified. It is recognized that "[the industry] needs to know the quality of milk that is being picked up from the processors"; however, trust concerns result in suspicions relating to data adjustment by processors. This may, in part, be related to competitiveness between processors.

Negative stakeholder relations feed into trust concerns. One participant reported: "We're seen as mud by $<$ a specific organization $>$, they have difficulties working with the practical side of actively working together, and we need to build trust, but it's difficult to do this when that perception is there." A second commented: "It's challenging to work together, we're not always perceived in the best light by others around the table." To which another participant clarified: "< Service provider $>$ is regarded as easy targets, as to why there is not better improvement on the ground." The basis of these identities is not clear from the data, though one reference is made to "a bad relationship in the past with $<$ a specific organization $>$...they don't understand that we have a bottom line, and we're seen as the culprits for not addressing cell count levels." It is clear that such perceived identities collectively affect trust and the perceived efficacy of stakeholders to contribute. The lack of trust between stakeholders prevents greater participation in the collective process.

Conditional Cooperation: Lowered Expectations on Stakeholder Ability to Commit. Concern was raised by over three-quarters of participants on the inability of the industry to reach its potential because of an inactive approach and lack of stakeholder response to actively improve quality standards. Despite a shifting of responsibility to other stakeholders, participant comments reflected lowered expectations of the ability of other stakeholders to commit to milk quality improvement, and consequently a lack of acknowledgment on their own responsibility to act. This participant explained: "We need more than others just saying yes at meetings, there needs to be more action than that, but I don't see that happening." Elaborating, the participant said: "It's difficult for any one group to take the lead $<$ on milk quality improvement $>$, especially as there is a huge inertia to [say] 'let's tackle this problem."' The concept of conditional cooperation is clear in the following statements, as stakeholders looked toward the contribution of others: "If $<$ milk processor $>$ isn't going to act on, well then why should we?"; and "We're left with the cost of doing. Farmers paying us $<$ service provider $>$ is the greatest challenge, where is $<$ other stakeholder group > in this, where is their support?" One participant clarified that lowered expectations arise from a "lack of understanding on why they $<$ industry stakeholders > should bother."

Conditional cooperation arises from how stakeholders believe they are perceived by other stakeholders and the effect of this perception on their contribution to quality improvements: "The intention $<$ to change the price structure for milk $>$ could be seen, seen as price fixing or a way of getting money. Farmers think this and feed into the farmers union." The perceived lack of active commitment among other stakeholders, in turn, affects stakeholders own perception of their responsibility to act. Responsibility is shifted elsewhere, yet a perceived inactivity among other stakeholders reduces the perceived need for stakeholders themselves to contribute.

\section{Opportunities to Achieving Collective Action Toward Improved Milk Quality in Ireland}

Though more emphasis was placed on the constraints, the potential role of $\mathrm{AHI}$ in facilitating collective action was widely discussed.

All 12 participants identified the beneficial facilitative role of AHI, which was identified as providing an opportunity for "more cooperation between professions"; "getting more people to use the same language, increased cooperating between stakeholders"; "of being inclusive"; and "coming at it from combined industry approach." Emphasizing the necessity of cooperation, AHI is described by one participant as providing a conduit for "good relationships and partnerships to develop that will help build trust and facilitate the sharing of data...to use people's data without being worried." Similarly, this participant noted that, "participation in AHI will mean that we will all have to act together, and work together." AHI is also seen as providing an opportunity to "demonstrate the incredible value of working together... of being inclusive, and breaking down the barriers." The identified strengths of AHI include its independent status, its perceived nonpolitical stance, its "clear, coordinated campaign, and consistent approach," and its role in providing science-based, best practice information. Interestingly, results show that despite areas of disagreement, shifting of responsibility, negative perceptions of stakeholder relations, and trust concerns, an ability among the participant group to recognize the value and need to work together exists. 


\section{DISCUSSION}

\section{The Imperative for Change}

The Irish dairy industry is heavily reliant on both retaining and expanding international markets. Milk quality is central to competitive advantage, particularly with high-value products such as infant formula and milk protein concentrates. The national industry is relatively fragmented, with a limited tradition of a collective, national approach to solving industry problems. Previous attempts to tackle milk quality were centered on one agency, usually focused on one regional area, thus diluting the actions of other agencies. As a public good and private good, milk quality presents broad, overall benefits to Ireland and the Irish dairy industry, and individual benefits to those within the industry. Given the lack of successful attempts in the past, the need for collective action is clear.

\section{The Application of Collective Action Theory}

In this study, the theoretical framework of collective action is employed to gain an understanding of constraints and opportunities to working collectively on milk quality improvement in Ireland. The results show that the theoretical insights into how stakeholders see their own and others responsibility (challenge 1, from the Introduction), the tendency for free-riding (2), the emergence of veto players (3), and the tendency for conditional cooperators (4) are applicable to understanding the constraints to collective action in the Irish dairy industry. Based on the results, the framework of these 4 points of collective action is useful, as it allows AHI to deal with expressed and hidden motives among stakeholders.

How Stakeholders See Their Own and Others' Responsibility. The propensity for collective action on improving milk quality is reduced because of a shifting of perceived responsibility for improvement (Kreps et al., 1982; Ostrom, 2000) to other industry stakeholders - particularly those at the processing, advisory, and government levels.

The Tendency for Free-Riding. The shifting of responsibility (and the associated costs) to other stakeholders, because of their perceived advantageous position, leads to the tendency for free-riding to occur. A shifting of responsibility to other stakeholders, and views toward the role of DAFM, may suggest a lack of understanding of quality milk in the context of both public good and private good. Governments are often the central players in the control of regulatory animal diseases, and it is often presumed by industry stakeholders that this responsibility should carry over to the management of nonregulatory diseases (More et al., 2011). Nonregulatory animal health is less distinguishable as a public good, given the precise involvement of, and direct benefit to, some stakeholders (such as dairy farmers) more so than the general public (More et al., 2011). Understanding milk quality as a public good (as well as a private good) changes the incentive structure of individual stakeholders, encouraging a focus on a more collective horizon.

The Emergence of Veto Players. The emergence of veto players is recognized as an important feature of agri-politics in Ireland. Results show the predominance of political and economic positions for some stakeholders in their willingness to act on milk quality improvements; as elsewhere, a complex network of negative relations is reported. These results may suggest that, rather than the prioritization of individual positions over a collective response, these positions may not be aligned with the industry direction. Reference to the prioritization of positions over the common good of the industry may reflect a lack of trust in other stakeholders and the lack of a common, collective voice. Nevertheless, the potential for veto players and trust concerns can contribute to the emergence of conditional cooperators, as stakeholders perceive the willingness of others to contribute when determining their own contribution.

The Propensity for Conditional Cooperators. The propensity for conditional cooperators (Ostrom, 2000; Potette et al., 2010) to emerge exists, as individual stakeholders base their potential for action on the perceived willingness and commitment of other stakeholders within AHI. Low expectations of others, negative perceptions of stakeholders, and low levels of trust reduce further the propensity for cooperation. Being able to demonstrate to the other actors that $\mathrm{AHI}$ is impartial, and not working from a position to maximize its own gain, has been salient in the context of Ireland's efforts to improve SCC. Given this background, AHI has been better positioned to propose a case for collective action.

\section{Promoting Ongoing Collective Action: Overcoming Constraints While Promoting Opportunities}

The literature points to the centrality of facilitated communication processes and a collective identity (Ostrom et al., 1992; Sally, 1995; Klandermans et al., 2002), an initiator who can devise strategies for collective action (Bianchi, 2001; Lamprinopoulou et al., 2006), and good trust relations when building collective action (Raymond, 2006) as important factors in promoting ongoing collective action.

What's Important for AHI to Consider when Promoting Collective Action. Animal Health Ire- 
land must continue to facilitate an environment where a culture of trust among stakeholders supports open communication and cooperation. Considering the multi-stakeholder nature of the Irish dairy industry, it has to be recognized that different challenges, incentives, and horizons exist for different groups, and that the same incentive may operate to a greater or lesser extent for any one stakeholder. For some individual stakeholders, action can only take place at an individual level; however, individual actions aimed toward overall quality improvement can be used as signals for other stakeholders to take initiative. Considering the role of expectations in informing stakeholder perceptions about different stakeholders, an altruistic or initiating stakeholder must not encourage a lessening of responsibility or others to become bystanders, but, instead, must serve to motivate and signal to surrounding members. An understanding and awareness of the potential gains to be achieved by contributing to the collective good can serve to encourage meaningful contribution to aggregate action (Hardin, 2002). As shown in the results, stakeholders recognize that AHI presents an opportunity for stakeholders to collectively come together. The following initiatives form part of the ongoing story of AHI and show pragmatic examples of where opportunities for collective action are being utilized and progress to tackling milk quality is being made. These are early attempts at enabling change and, undoubtedly, the effectiveness of these initiatives will be tracked as they progress.

The CellCheck Program: Providing a Coordinated Approach. CellCheck, the national mastitis control program, is being developed and delivered in partnership with industry bodies representing farmers, processors, service providers, and government. To this point, technical research has focused on an objective assessment of changes to udder health and intramammary antibiotic usage (More et al., 2012) and the effect of SCC data adjustment and interpretation, as outlined in EU legislation, on herd eligibility to supply raw milk for manufacture of milk products for human consumption. CellCheck aims to deliver a team-based approach, at a local level, to improving udder health and solving milk quality problems. A key part of the infrastructure to deliver such an approach will be regional coordinators. To gain an understanding of the potential role of these coordinators, social science research is being carried out on their possible functions and the challenges involved in establishing such intermediaries (Ryan et al., 2012). CellCheck is also creating science-based resources (e.g., Farm Guidelines for Mastitis Control); this resource has been a collective industry effort involving (among other disciplines) dairy scientists, and is a collation of the most up-to-date national and international research on mastitis control. This resource ensures that an agreed upon source of evidence-based, independent information is available for farmers and their service providers.

CellCheck ICG: Building Trust and Open Cooperation. CellCheck ICG was established to provide a platform for stakeholder perspectives, both negative and positive. Stakeholders are brought together to focus on a single issue where objective evidence of a problem exists. Open discussions have commenced around milk payment structures and the sharing of objective SCC data, which has contributed to improved trust-based relations with greater transparency and a greater focus on achievable gains. This has also included quantifying the economic losses on farms associated with reduced milk quality (Geary et al., 2012), outlining Ireland's position in relation to the global market in infant milk, and a discussion on what quality should translate to (i.e., moving away from a definition based on the regulatory standard for SCC of 400,000 cells/mL in milk). These initiatives have helped position milk quality as a public good while providing a better understanding of what's required to achieve meaningful improvement.

The Role of AHI: Building Stakeholder Consensus. Animal Health Ireland uses a technical, multilateral, partnership approach to problem solving and provides a platform to bring together individual, sectorial perspectives to actively create a common framework in which recognition of individual responsibilities can be promoted and harnessed toward contributing collectively to milk quality improvement. This study has helped clarify some of the most important nontechnical constraints to progress, issues that are now being discussed in detail within CellCheck ICG. Pertinent to dairy scientists, work is ongoing to build infrastructure to support change; including up-skilling of relevant service providers, a consistent national message regarding SCC targets and mastitis control solutions, and the development of a broad range of on- and postfarm awareness and decision support tools, such as an on-farm SCC cost calculator (Geary et al., 2012) and informative farm reports. It is likely that sustainable change will require a collective agreement to change milk pricing structure.

Given the mixture of a public and private good element to milk quality, in the absence of a collective action approach, much of the best practice toward improving udder health and milk quality developed by dairy scientists may not be utilized by dairy farmers. As trust and a collective identity is built among stakeholders - as a result of interaction through AHI and the various initiatives outlined above - experiences, particularly in relation to on-farm udder health and milk quality practices, as well as resources and expertise, will be exchanged. This knowledge, when relayed back 
to dairy scientists, can inform future research around best practice.

\section{ACKNOWLEDGMENTS}

The authors express their gratitude to all participants who took part and to AHI for their support in conducting this study.

\section{REFERENCES}

Adger, W. N. 2003. Social capital, collective action, and adaptation to climate change. Econ. Geogr. 79:387-404.

Ahn, T. K., E. Ostrom, D. Schmidt, R. Shupp, and J. Walker. 2001. Cooperation in PD games: Fear, greed, and history of play. Public Choice 106:137-155.

Anker, A. E., and T. H. Feeley. 2011. Are non-participants in prosocial behavior merely innocent bystanders? Health Commun. 26:13-24.

Armentano, L., W. Dobson, E. Jesse, and N. Olson. 2004. The Dairy Sectors of New Zealand and Australia: A Regional Study. Babcock Institute, University of Wisconsin, Madison.

Attride-Stirling, J. 2001. Thematic networks: An analytic tool for qualitative research. Qual. Res. 1:385-405.

Bengtsson, M., and S. Kock. 2000. "Cooperation" in business networks - To cooperate and compete simultaneously. Ind. Mark. Manage. 29:411-426.

Bianchi, T. 2001. With and without co-operation: Two alternative strategies in the food-processing industry in the Italian south. Entrepreneurship Reg. Dev. 13:117-145.

Brightling, P., A. Hope, A. Thompson, and R. Dyson. 2005. Building industry capacity to control mastitis and manage milk quality. Dairy Australia, Melbourne.

Central Statistics Office. 2010. Census of Agriculture 2010-Preliminary Results. Accessed Oct. 24, 2012. http://www.cso.ie/en/ media/csoie/releasespublications/documents/agriculture/2010/ coapre2010.pdf.

Cook, M. 1997. Organisational structure and globalisation: The case of user oriented firms. Page 77-94 in Strategies and Structures in the Agro-Food Industries. J. Nilsson and G. van Dijk, ed. Van Gorcum, Assen, the Netherlands.

Creighton, P., E. Kennedy, L. Shalloo, T. M. Boland, and M. O' Donovan. 2011. A survey analysis of grassland dairy farming in Ireland, investigating grassland management, technology adoption and sward renewal. Grass Forage Sci. 66:251-264.

Delton, A. W., L. Cosmides, M. Guemo, T. E. Roberston, and J. Tooby. 2012. The psychosemantics of free riding: Dissecting the architecture of a moral concept. J. Pers. Soc. Psychol. 102:12521270 .

Department of Agriculture, Food and the Marine. 2010. Food Harvest 2020. A vision for Irish agri-food and fisheries. Accessed Apr. 27 2012. www.agriculture.gov.ie/media/migration/agri-foodindustry/ foodharvest2020/2020FoodHarvestEng240810.pdf.

Department of Agriculture, Food and the Marine. 2012. Fact Sheet on Irish Agriculture - April 2012. Accessed Apr. 27, 2012. www. agriculture.gov.ie/media/migration/publications/2012/Factsheet onIrishAgricultureApr12.pdf.

Doyle, P., J. Jacobs, and D. Henry. 2010. Dairy Moving Forward: Research, Development and Extension Priorities for the Australian Dairy Industry. Dairy Moving Forward, Victoria, Australia.

Fleishman, J. 1980. Collective action as helping behavior: Effects of responsibility diffusion on contributions to a public good. J. Pers. Soc. Psychol. 38:629-637.

Geary, U., N. Lopez-Villalobos, N. Begley, F. McCoy, B. O'Brien, L. O'Grady, and L. Shalloo. 2012. Estimating the effect of mastitis on the profitability of Irish dairy farms. J. Dairy Sci. 95:3662-3673.

Hardin, G. 1968. The tragedy of the commons. Science 162:12431248.
Hardin, R. 2002. The street-level epistemology of democratic participation. J. Polit. Philos. 10:212-219.

Heffernan, C., L. Nielsen, F. Misturelli, J. Yu, and G. Gunn. 2005. An Analysis of Pan-European Attitudes towards BVD Eradication and Control. Report for EU Thematic Group on BVD Control. Livestock Development Group, University of Reading, UK.

Heffernan, C., L. Nielsen, K. Thomson, and G. Gunn. 2008. An exploration of the drivers to bio-security collective action among a sample of UK cattle and sheep farmers. Prev. Vet. Med. 87:358-372.

Holcombe, R. 1997. The theory of the theory of public goods. Rev. Austrian Econ. 10:1-22.

International Dairy Federation. 2009. Bulletin of the International Dairy Federation 438/2009. The World Situation 2009. Accessed Nov. 9, 2012. http://www.lactodata.com/lactodata/docs/lib/fil_ idf_bulletin_438_2009_the_world_2009.pdf.

Irish Business and Employers Confederation. 2007. Business perspectives on future dairy policy: A discussion document compiled by the Irish Dairy Industries Association. Accessed Oct. 24, 2012. http://www.fdii.ie/Sectors/FDII/FDII.nsf/ vPages/Publications $\sim$ Publications_archive business-perpectiveson-future-dairy-policy/\$file/Business \%20Perspectives\%20on $\% 20$ Future\%20Dairy\%20Policy.pdf.

Irish Business and Employers Confederation. 2011. Support an Irish Success Story. Policy Recommendations of the Food and Drink Sector - 2011. Accessed Oct. 24, 2012. www.fdii.ie/Sectors/ FDII/FDII.nsf/vPages/Publications policy-recommendationsof-the-food-and-drink-sector-2011/\$file/FDII\%20Policy $\% 20$ Recommendations\%202011.pdf.

Kaul, I., and D. Gleicher. 2011. Governing Global Health: Is Europe Ready? Global Health Europe Research Paper No. 3. Global Health Programme, Geneva, Switzerland.

Klandermans, B., J. M. Sabucedo, M. Rodriquez, and M. De Weerd. 2002. Identity processes in collective action participation: Farmers identity and farmers' protest in the Netherlands and Spain. Polit. Psychol. 23:235-251.

Kreps, D. M., P. Milgrom, J. Roberts, and R. Wilson. 1982. Rational cooperation in the finitely repeated prisoner's dilemma. J. Econ. Theory 27:245-252.

Lamprinopoulou, C., A. Tregear, and M. Ness. 2006. Agrifood SMEs in Greece: The role of collective action. Br. Food J. 108:663-676.

Le Cren, N., J. Lyons, and L. P. Dana. 2009. The role of collective action in the New Zealand dairy industry: An international comparison. Int. J. Entrepreneurship and Small Business 8:154-169.

Libecap. 1989. Contracting for Property Rights. Cambridge University Press, Cambridge, UK

Meinzen-Dick, R., M. Di Gregorio, and N. McCarthy. 2004. Methods for studying collective action. Rural Dev. Agric. Syst. 82:197-214.

More, S. J. 2007. Shaping our future: Animal health in a global trading environment. Ir. Vet. J. 60:540-545.

More, S. 2009. Global trends in milk quality: Implications for the Irish dairy industry. Ir. Vet. J. 62(Suppl. 4):S5-14.

More, S. J., T. A. Clegg, and L. O'Grady. 2012. Insights into udder health and intramammary antibiotic usage on Irish dairy farms during 2003-2010. Ir. Vet. J. 65:7.

More, S. J., M. L. Doherty, J. O'Flaherty, L. Downey, K. McKenzie, and C. Devitt. 2011. Animal Health Ireland: Providing national leadership and coordination of non-regulatory animal health issues in Ireland. Rev. Sci. Tech. Off. Int. Epizoot. 30:715-723.

More, S. J., K. McKenzie, J. O'Flaherty, M. L. Doherty, A. R. Cromie, and M. J. Magan. 2010. Setting priorities for non-regulatory animal health in Ireland: Results from an expert Policy Delphi study and a farmer priority identification survey. Prev. Vet. Med. 95:198-207.

Nettle, R., P. Brightling, and J. Williamson. 2010. Building capacity in collective action: learning from dairy industry workforce planning and action in Australia. Pages 207-217 in 9th European IFSA Symposium, Vienna, Austria. Universität für Bodenkultur, Vienna, Austria.

Nilsson, J., and G. van Dijk, eds. 1997. Strategies and Structures in the Agro-Food Industries. Van Gorcum, Assen, the Netherlands. 
Olson, M. 1971. The Logic of Collective Action. Harvard University Press, Cambridge, MA.

Ostrom, E. 1990. Governing the Commons: The Evolution of Institutions for Collective Action. Cambridge University Press, Cambridge, UK.

Ostrom, E. 2000. Collective action and the evolution of social norms J. Econ. Perspect. 14:137-158.

Ostrom, E., J. Walker, and R. Gardner. 1992. Covenants with and without a sword: Self-governance is possible. Am. Polit. Sci. Rev. $86: 404-417$.

Potette, A., M. Janssen, and E. Ostrom. 2010. Working Together? Collective Action, the Commons and Multiple Methods. Princeton University Press, Princeton, NJ.

Powell, R. 2008. 10: Private good, public goods and externalities. AQA AS Economics. Philip Allan, Oxfordshire, UK.

Raihani, N., and D. Aitken. 2011. Uncertainty, rationality and cooperation in the context of climate change. Clim. Change 108:47-55.

Raymond, L. 2006. Cooperation without trust: Overcoming collective action barriers to endangered species protection. Policy Stud. J. 34:37-57.

Ryan, C., K. Heanue, and F. Devitt. 2012. Evolving innovation support arrangements: A focus on innovation brokering. Teagasc Best Practice in Extension Services Conference-Supporting Farmer Innovation. K. Heanue, A. Macken-Walsh, and P. Maher, ed, Teagasc, Oak Park, Ireland.

Sally, D. 1995. Conservation and cooperation in social dilemmas: A meta-analysis of experiments from 1958-1992. Rationality Soc. 7:58-92.

Sandler, T. 1992. Collection Action: Theory and Applications. Harvester Wheatsheaf, New York, NY.
Sandler, T. 2004. Global Collective Action. Cambridge University Press, Cambridge, UK.

Schwartz, S. H., and A. Gottlieb. 1976. Bystander reaction to a violent theft: Crime in Jerusalem. J. Pers. Soc. Psychol. 34:1188-1199.

Sharpe, S. 1990. Asymmetric information, bank lending and implicit contracts: A stylized model of customer relationships. J. Finance 45:1069-1087.

Stern, N. 2007. Stern Review of the Economics of Climate Change. Part VI: International Collective Action. HM Treasury, London, UK.

Stigler, G. 1974. Free riders and collective action: An appendix to theories of economic regulation. Bell J. Econ. 5:359-365.

Stone, R. D. 1991. The Interstate Commerce Commission and the Railroad Industry: A History of Regulatory Policy. Praeger, New York, NY.

Stroebe, W., and B. Frey. 1982. Self-interest and collection action: The economics and psychology of public goods. Br. J. Soc. Psychol 21:121-137.

Szolnoki, A., and M. Perc. 2012. Conditional strategies and the evolution of cooperation in spatial public good games. Phys. Rev. E Stat. Nonlin. Soft Matter Phys. 85:026104.

Tingley, D., and M. Tomz. 2012. Conditional cooperation and climate change. http://scholar.harvard.edu/files/tingleytomzclimatefinal_0.pdf.

Tsebelis, G. 1995. Decision making in political systems: Veto players in presidentialism, parliamentarism, multicameralism and multipartyism. Br. J. Polit. Sci. 25:289-325.

Tsebelis, G. 2002. Veto Players: How Political Institutions Work. Princeton University Press, Princeton, NJ. 